\title{
XENOBIOTIC INDUCED MODEL OF PRIMARY BILIARY CIRRHOSIS
}

Aleksandar Arsenijevic ${ }^{1}$, Jelena Milovanovic ${ }^{1}$, Bojana Stojanovic ${ }^{1}$, Marija Milovanovic ${ }^{1}$, Eric M. Gershwin ${ }^{2}$,

Patrick Leung ${ }^{2}$, Nebojsa Arsenijevic ${ }^{1}$, Miodrag L. Lukic ${ }^{1}$

${ }^{1}$ Center for Molecular Medicine and Stem Cell Research, Faculty of Medical Sciences, University of Kragujevac, Serbia

${ }^{2}$ Division of Rheumatology, Allergy and Clinical Immunology, University of California, Davis, CA, USA

\section{PRIMARNA BILIJARNA CIROZA INDUKOVANA IKSENOBIOTIKOM: EKSPERIMENTALNI MODEL}

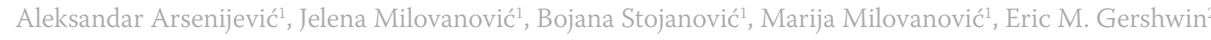 \\ Patrick Leung ${ }^{2}$, Neboiša Arsenijević ${ }^{1}$, Miodrag L. Lukić \\ ${ }^{1}$ Centar za molekulsku medicinu i ispitivanje matičnih ćelija, Fakultet medicinskih nauka, Univerzitet u Kragujevcu, Srbija \\ ${ }^{2}$ Odeljenje reumatologije, alergologije i kliničke imunologije, Univerzitet u Kaliforniji, SAD
}

\section{ABSTRACT}

Primary biliary cirrhosis (PBC) is an autoimmune disease of the liver that is, characterised by destruction of the intrahepatic bile ducts and the presence of antimitochondrial antibodies (AMAs). Several murine models of PBC, with similar serological, biochemical, and histological features to human $P B C$, have been developed in recent years. These animal models enable investigators to study the etiology and pathophysiologic mechanism of $P B C$. Immune response in $P B C$ is directed towards E2 components of the 2-oxo-acid dehydrogenase family of enzymes, which is in located in mitochondria and is an immunodominant epitope (a lipoylated peptide sequence shared by enzymes). Immunisation of mice with 2-octynoic acid coupled to bovine serum albumin (2-OA-BSA) (which is an antigen that is structurally related to the E2 subunit of the pyruvate dehydrogenase complex [PDC-E2]) produces histologic features similar to those found in human PBC. This model of xenobiotic induced $P B C$ is suitable for studying the early events in $P B C$ pathogenesis and for developing new therapeutics in $P B C$.

Key words: $P B C$, xenobiotic, $2 O A-B S A, C 57 B L / 6$ mice

\section{SAŽETAK}

Primarna bilijarna ciroza (PBC) je autoimunska bolest jetre koju karakteriše destrukcija intrahepatičnih žučnih kanalića $i$ prisistvo antimitohondrijalnih antitela (AMAs). Poslednjih godina je razvijeno nekoliko mišjih modela PBC koji imaju slične serološke, biohemijske i histološke karakteristike kao i humana PBC. Ovi animalni modeli su omogućili ispitivanje etiologije $i$ mehanizama uključenih u patogenezu PBC. U PBC imunski odgovor je usmeren na E2 komponentu 2-okso-kiseline dehidrogenaza familije enzima koji su locirani u mitohondrijama, a imunodominantni epitop je peptidna sekvenca sa lipidima koja je zajednička za ove enzime. Imunizacija miševa 2-oktinoičnom kisleinom vezanom za govedi serumski albumin (2-OA-BSA), antigenom koji je strukturno sličan E2 subjedinici kompleksa piruvat dehidrogenaze (PDC-E2), omogućava razvoj histoloških promena koje karakterišu PBC kod ljudi. Ovaj model PBC indukovan ksenobiotikom je pogodan za ispitivanje početnih dogadaja u patogenezi PBC i za razvoj novih lekova za PBC.

Ključne reči: $P B C$, ksenobiotik, 2OA-BSA, C57BL/6 miševi

\section{INTRODUCTION}

Primary biliary cirrhosis (PBC) is a liver-specific autoimmune disease (1). PBC has a long latency period, which is followed by the development of common symptoms: fatigue, pruritus hyperpigmentation, and (in the terminal stages) bleeding varices, and ascites (2). PBC is characterised by a multilineage humoral and cellular adaptive response against biliary epithelial cells (BECs) and destruction of small bile ducts by mechanisms that include innate immune responses $(3 ; 4)$. Bile duct destruction leads to cholestasis, fibrosis, and ultimately liver cirrhosis (4). The typical characteristic of the disease is the presence of an- timitochondrial autoantibodies (AMA), which are present in high amounts. The autoantigens to which the immune responese is directed in $\mathrm{PBC}$ has been identified as the E2 subunits of the 2-oxo-acid dehydrogenase complexes (2OADC-E2), including the E2 subunits of the pyruvate dehydrogenase complex (PDC-E2), branched chain 2-oxo acid dehydrogenase complex (BCOADC-E2), and 2-oxoglutarate dehydrogenase complex (OGDC-E2) (5). The immunodominant autoantigen within this group is PDCE2 $(6 ; 7)$. A multi-faceted immune response to the immunodominant mitochondrial autoantigen PDC-E2 in PBC 
suggests that a loss of tolerance to PDC-E2 is the initiating event in the development of $\mathrm{PBC}$; there is no significant evidence of epitope spreading, which is present in other autoimmune diseases (8).

\section{ETIOPATHOGENESIS OF PBC}

The etiology of PBC, including the loss of tolerance, is still unknown. However, as in all autoimmune diseases, it is likely that genetic susceptibility and environmental factors play a role in the pathogenesis (9). Environmental factors, including xenobiotics or microorganisms, modify the autoantigen and facilitate the breakdown of tolerance (10).

Molecular mimicry: Cross-reactivity between sera of $\mathrm{PBC}$ patients and $E$. coli has been shown, but stronger reactivity (1,000-fold stronger than with E. coli) has been demonstrated with the xenobiotic-metabolising gramnegative bacterium Novosphingobium aromaticivorans (a bacterium present in human fecal specimens) (11). N. aromaticivorans contains two proteins highly homologous to the immunodominant epitope of PDC-E2 and serum autoantibodies. Importantly, mice infected with $N$. aromaticivorans deveope PBC-like liver lesions (12).

Xenobiotics: Because the liver plays a key role in the metabolism of toxins, the hepatocytes and BECs are continuously exposed to chemical by-products. Associations between $\mathrm{PBC}$ and the frequent use of nail polish support a xenobiotic pathogenesis hypothesis. 2-Octynoic acid is a food additive and xenobiotic that is present in cosmetic products, such as nail polish. The in vitro and in vivo data strongly support a potential role of 2-octynoic acid in PBC. Reactivity of 2-octynoic acid with AMAs and lipoic acid has been shown (13). Congenic nonobese diabetic NOD.1101 (NOD.B6 Idd10 Idd18r2) C57BL/6 mice, immunised with 2-octynoic acid conjugated with bovine serum albumin, develop histological features of autoimmune cholangitis (portal infiltrates enriched in CD8+ cells and liver granulomas); these mice demonstrated high titers of AMAs (14-17). This model provides convincing evidence that xenobiotics are causally related to the development of PBC.

\section{Biliary epithelial cells}

The most intriguing aspect of the pathogenesis of $\mathrm{PBC}$ remains the specific immune response directed at the small intrahepatic bile ducts, as all nucleated cells have mitochondria with 2-oxo-acid dehydrogenase complexes. These small biliary ducts are lined with biliary epithelial cells, BECs (i.e., cholangiocytes) and are destroyed by the immune response, mediated by specific CD4+ and CD8+ $\mathrm{T}$ cells $(18 ; 19)$. This selective destruction indicates there are unique immunopathological characteristics of BECs. It is known that BECs are not passive bystanders in primary biliary cirrhosis; these cells can increase the expression of adhesion molecules and production of TNF- $\alpha$, IFN- $\gamma$, and IL-1 upon stimulation with proinflammatory cytokines (20). Through the variable expression of adhesion molecules and proinflamamtory cytokines, BECs can modulate the degree and localizisation of the inflammatory process. Additionally, BECs have properties of antigen presenting cells by expressing HLA class II and costimulatory molecules CD80 and CD86. Based on these characteristics of BECs, it can be hypothesizised that their interactions with $\mathrm{T}$ cells may be responsible for bile duct damage.

BECs of small bile ducts are very susceptible to apoptosis, more than epithelial cells of larger ducts (due to a lack of production of specific protease-resistant peptides, trefoils) (21). Moreover, unique characteristics of apoptosis in BECs indicate that this process most likely plays a part in the immunopathogenesis of PBC. Autoreactive lymphocytes may be activated with neo-antigens arise from apoptotic BECs (22). When BECs undergo apoptosis, the major mitochondrial autoantigen, PDC-E2, remains immunologically intact, whereas other cells following apoptosis present a form of PDC-E2 that cannot be detected by AMAs (23; 24). Persistent exposure to PDC-E2, as derived from BECs, is caused by a failure to covalently link PDCE2 to glutathione during the course of apoptosis in these cells. Another important observation regarding the role of apoptotic BECs in the pathogenesis of $\mathrm{PBC}$ is the high degree of proinflammatory cytokine production in monocyte-derived macrophages that was found in PBC patients who were incubated with apoptotic bodies from BECs (in the presence of AMAs) (25). It is important to note that the BECs used in these experiments were derived from two normal donors, which implies that there is no phenotype of biliary epithelial cells specific for $\mathrm{PBC}$; this could explain the recurrence of $\mathrm{PBC}$ following transplantation (26).

Immunostaining of $\mathrm{PBC}$ biliary tract with monoclonal antibodies against mitochondrial autoantigens demonstrated a high degree of expression of PDC-E2 at the apical surface of the small bile duct cells lining the bile duct lumen (27; 28). Cholangiocytes play a role in the transport of IgA antibodies in bile duct lumen. PDC-E2-specific IgA enters the BECs via a polyimmunoglobulin receptor and forms a complex with PDC-E2; it may thereby contribute to the exposure of PDCE2 at the apical surface of BECs. Additionally, during transcytosis through cells expressing polyimmunoglobulin receptors, dimeric IgA can initiate the activation of caspases (29). The levels of anti-PDC-E2 IgA antibodies in PBC sera directly correlate with the level of caspase activation.

\section{IMMUNE RESPONSE IN PRIMARY BILIARY CIRRHOSIS}

The mechanism of biliary destruction has not been completely determined, but the specificity of pathological changes in the bile ducts, the presence of lymphoid infiltration in the portal tracts, and the presence of majorhistocompatibility-complex class II antigens on the biliary epithelium indicate that an intense immune response is directed against the biliary epithelial cells. There are data suggesting that the destruction of biliary cells is mediated by liver-infiltrating autoreactive T cells $(19 ; 30)$. CD4+ and 
CD8+ T cells can be detected in the portal tracts of PBC patients (19; 31-33). An increased serum level of autoantibodies specific for PDC-E2 is accompanied by a 100 times higher frequency of antigen-specific CD4+ T cells and a 10 times higher frequency of antigen-specific CD8+ T cells in liver as compared towith draining lymph nodes. Two important $\mathrm{T}$ helper cell subpopulations shown to have a role in the pathogenesis of PBC are Th17 and Treg cells (34). Significantly lower levels of CD4+ CD25high are detected in the peripheral blood of $\mathrm{PBC}$ patients and their family members. In addition, FoxP3+ Treg cells can be detected in the lymphoid infiltrates found in the portal tracts (35). Th17 cells have a pathogenic role in PBC: an increased frequency of IL-17-positive lymphocytes was found in liver tissues from patients with PBC, and in the IL-2R $\alpha \mathrm{KO}$ mouse model of autoimmune biliary disease (36).

There is granulomatous inflammation in the liver of PBC patients that is accompanied by an increased production of polyclonal IgM antibodies. Cultured human BECs express toll like receptors (TLRs), lipopolysaccharide, and lipoteichoic acids, which are present in bile. The eExpression of TLRs in BECs is mediated through biliary injury via the NF- $\mathrm{kB}$ pathway (37). In response to TLR stimulation, BECs may produce proinflammatory cytokines IL- 6 and TNF- $\alpha$ and chemokines IL-8 and CX3CL1. CX3CL1 is a chemoattractant for cells expressing its receptor, CX3CR1. In PBC patients, CX3CR1 expressing CD8+ and CD4+ T cells can be found in the portal tracts and within the biliary epithelial layer of injured bile ducts (38). Another cell type known to be involved in PBC pathogenesis are NKT cells. There is a higher frequency of CD1d-restricted NKTs in PBC patients. These cells are more frequently found in the liver than in the peripheral blood. An increased number of CD1d-restricted NKT cells was found in the liver of the dnTGF- $\beta$ RII mouse model (39). These CD1drestricted NKT cells in the liver had increased IFN- $\gamma$ production following exposure to $\alpha$-galactosylceramide; this was accompanied by a decrease in hepatic lymphoid cell infiltration and less cholangitis when compared towith the controls.

\section{ANIMAL MODELS OF PBC}

Over the past several years, several animal models for PBC have been developed. Severe combined immunodeficient (SCID) mice develop lymphocytic infiltration around small bile ducts and present with the anti-PDC-E2 antibodies following the transfer of lymphocytes from peripheral blood of PBC patients (40). Congenic NOD.c3c4 mice are obtained by replacing the diabetes-susceptibility genes on chromosomes 3 and 4 with the diabetes-resistance genes of B6 and B10 mice (41). Overall, $50 \%$ to $60 \%$ of these mice develop autoimmune cholangitis and demonstrate AMA antibodies in their serum. Histologically, however, the cyst-like dilatation of the affected bile duct, which is characteristic of these mice, is not observed in PBC patients; when the dilatation becomes severe, the biliary epithelium of NOD.c3c4 mice frequently exfoliates, which can trigger neutrophil in- filtration that is not characteristic of human disease. Another mouse model for PBC is the dnTGF- $\beta$ RII mouse. These mice over express the dominant-negative form of TGF- $\beta$ receptor II under the control of the CD4 promoter. A deficiency of TGF- $\beta$ signalling causes various immunological abnormalities, including colitis. dnTGF- $\beta$ RII mice exhibit major serological and histological characteristics of human PBC (42), indicating an important role of the TGF- $\beta$ signalling pathway in the pathogenesis of $\mathrm{PBC}$. Serologically, specific AMA production occurs in all mice, and histologic hepatic lesions typical of PBC (lymphocytic infiltration, interlobular bile duct destruction, and granuloma formation in the portal tract) appear at an increased frequency. Immune infiltrating cells (including B cells, plasmacytoid dendritic cells, natural killer (NK) cells, and macrophages), CD4+ cells, and CD8+ $\mathrm{T}$ cells are found in the portal tracts. In IL-2R $\alpha-/-$ mice (43), the IL-2 signal, which is important for controlling the fate of mature $\mathrm{T}$ cells, is functionally blocked. These mice develop an inflammatory bowel disease and an autoimmune lymphoproliferative disease. Anti-PDC-E2 antibodies are present in the sera of all IL-2R $\alpha-/-$ mice. There is increased lymphocytic infiltration in the portal tract and damage of the interlobular bile duct. CD8+ $\mathrm{T}$ cells are predominant among the infiltrating lymphocytes, and there is an increase in the number of CD4+ T and B cells. In addition, a small number of granulomas is formed. Increased levels of inflammatory cytokines, including TNF- $\alpha$, IFN- $\gamma$, IL-12p40, and IL-6, are also observed. Using a model produced by crossing IL-2R $\alpha-/-$ mice with CD4 KO and CD8 KO mice, Hsu et al. (44) showed that CD8+ T cells participate in the pathogenesis of PBC.

\section{XENOBIOTIC INDUCED PBC}

The autoantigens of the E2 enzymes have a common structure consisting of a single $\mathrm{N}$-terminal catalytic domain, containing two binding sites for the covalently attached lipoic acid cofactor. These lipoyl binding domains are the epitopes that are recognizised most often by AMAs (8), suggesting an essential role of the lipoic acid domain in the etiology of PBC. The immune reactivity of AMAs are directed against a conformational epitope that is susceptible to chemical modification. This finding indicates that self-tolerance may be interrupted by chemical modification of the lipoyl domain of PDC-E2 by xenobiotics. It has been demonstrated that the modified lipoyl domain of PDC-E2 specifically binds antibodies in PBC sera, often at levels higher than the native PDC-E2 molecule (4547). These mimicking effects are found in compounds that are widely used in the environment (including perfumes, lipstick, and many common food flavorings) (45). Studies have shown that animals immunised with selected AMApositive xenobiotics resulted in AMAs; these animals developed liver pathology similar to PBC $(48 ; 49)$.

It has been reported that B6 and NOD.1101 (NOD. B6 Idd10 Idd18r2) mice immunised with 2-octynoic acid 

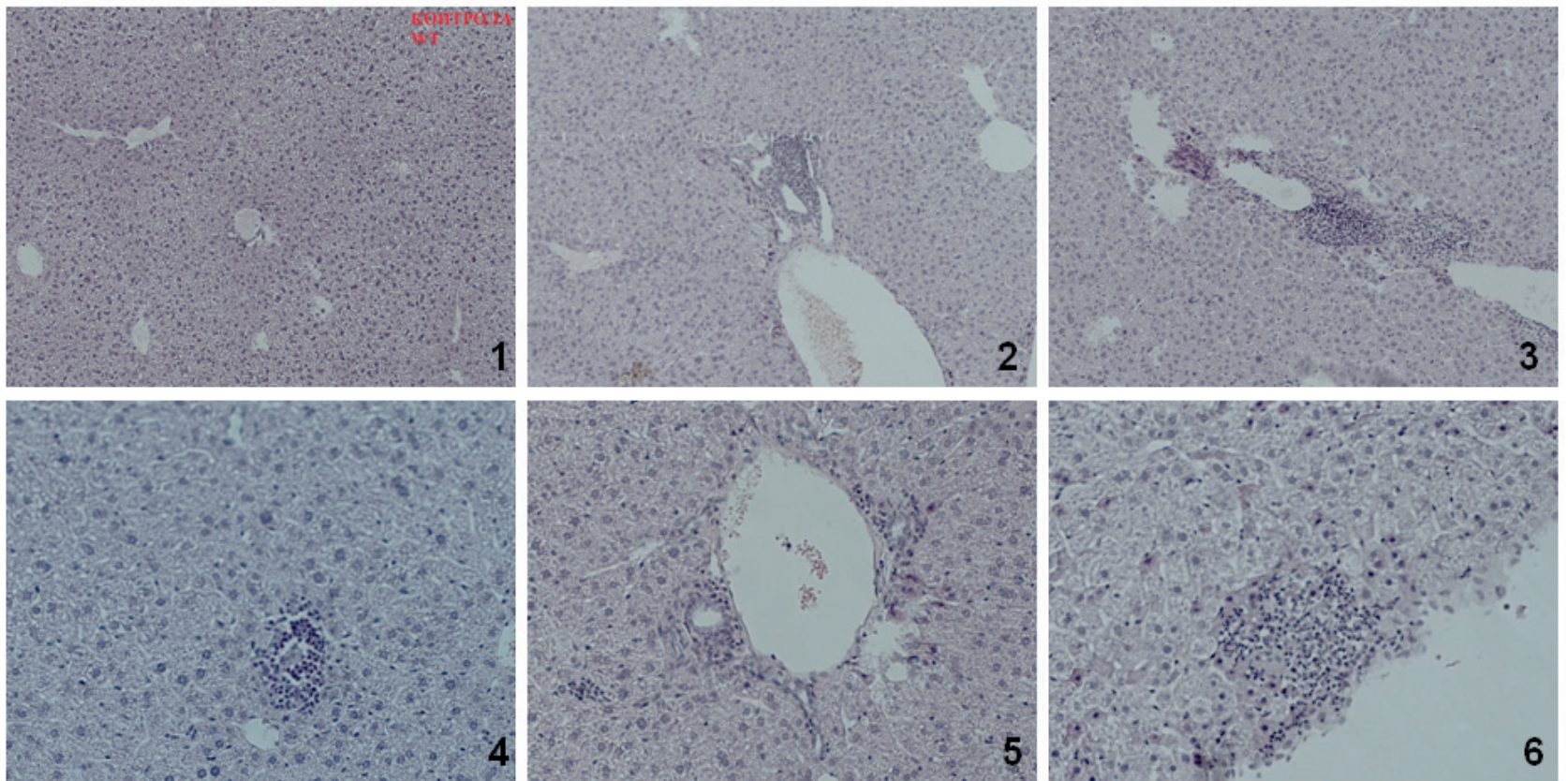

Figure 1. Histological features of the C57BL/6 mice 8 weeks after immunization with 2OA-BSA and control mice.

Different degrees of lymphocytic infiltration: 1) untreated mice; 2) portal infiltration with granuloma formation; 3) parenchymal infiltration;

4) parenchymal granuloma; 5) moderate portal infiltration; 6) subcapsular abscess (H\&E staining).

(2-OA), coupled to BSA, had high AMA titers, portal inflammation, and cholangitis similar to human PBC (14).

We used this xenobiotic induced PBC model to explore, in detail, the histological characteristics of the liver.

\section{EXPERIMENTAL PROTOCOL}

Female C57BL/6 mice were maintained at the animal facilities of the Faculty of Medical Sciences University of Kragujevac. All animal procedures were approved by the ethical committee of the Faculty of Medical Sciences, University of Kragujevac.

Primary biliary cirrhosis was induced as previusly described (14). Briefly, a mixture of BSA conjugated 2-octynoic acid (2OA-BSA; $100 \mu \mathrm{g} / 100 \mu \mathrm{L}$ in PBS) was injected intraperitoneally with Complete Freund's Adjuvant (CFA; Sigma-Aldrich, St. Louis, MO), containing $1 \mathrm{mg} / \mathrm{mL}$ of Mycobacterium tuberculosis (strain H37 RA; Difco Laboratories, Detroit, MI). This was subsequently boosted every two weeks with 2OA-BSA in Incomplete Freund's Adjuvant (IFA; Sigma-Aldrich, St. Louis, MO). Additionally, mice intraperitoneally received $100 \mathrm{ng}$ of pertussis toxin (List Biological Laboratories, Campbell, CA) at the time of initial immunisation with 2OA-BSA in Complete Freund's Adjuvant.

Immediately following sacrifice, liver tissue was harvested, fixed in $10 \%$ buffered formalin, embedded in paraffin, and cut into 4- $\mu \mathrm{m}$ sections for routine hematoxylin and eosin (H\&E) staining. Evaluation under light microscopy and scoring of liver inflammation and bile duct damage was performed on coded H\&E-stained sections in a

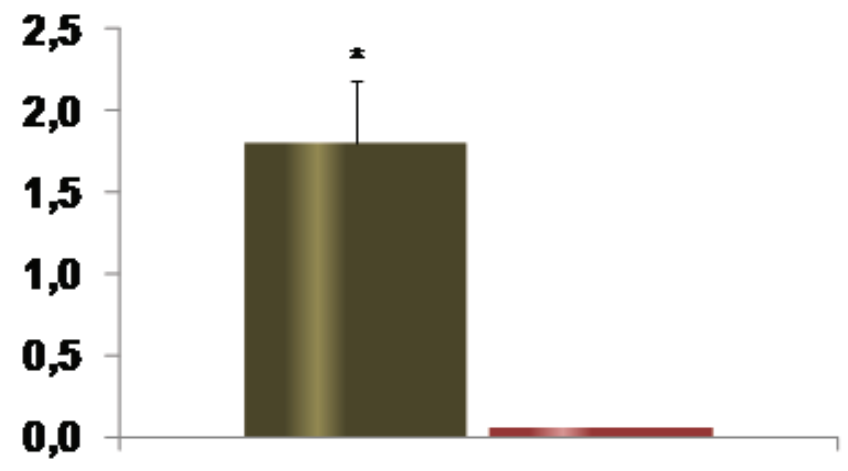

Score I

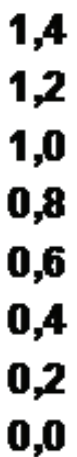

1,4
1,2
1,0
0,8
0,6
0,4
0,2
0,0

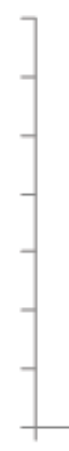

2OA-BSA control

Figure 2. C57BL/6 mice immunized with 2OA-BSA develop significant infiltrates in the liver. Mean values + SD for histopathological scores I and II per group (2OA-BSA immunised and control) are presented. $0=$ no significant change, $1=$ minimal, $2=$ mild, $3=$ moderate, and $4=$ severe pathology $* \mathrm{p}<0.05$. 
blinded fashion. The images were captured with a light microscope (Olympus) equipped with a digital camera.

Sections were evaluated for periportal inflammation, infiltration of bile ducts without damage, infiltration and damage of bile ducts, and subcapsular infiltrates. Based on the level of pathology, the indices were scored as 0 , no; 1 , mild; 2 , moderate; 3 , severe; or 4 , very severe pathology. Score I was calculated as the mean value of each scored index. Granulomas, and fibrosis were scored as 0 , no; 1 , mild; 2 , moderate; or 3 , severe pathology; , based on these values, score II was calculated.

All mice immunised with 2OA-BSA (9/9) developed histological findings typical of PBC (Figure 1). Our histological scoring clearly demonstrates the disease in the group of 2OA-BSA immunised mice (Figure 2).

The autoimmune cholangitis induced by 2OA-BSA immunisation recapitulates the histological features of human PBC: portal-tract inflammation with destruction bile ducts, focal-duct obliteration with granuloma formation, periportal extension of inflammation, and fibrosis. Importantly this model of autoimmune cholangitis gives us the opportunity to study the early events of $\mathrm{PBC}$ pathogenesis and to explore the possibility of new PBC therapeutics.

\section{ACKNOWLEDGMENTS}

This work was funded by grants from the Serbian Ministry of Science and Technological Development (Grants No. ON175071, ON175069, and ON175103), Serbia and The Faculty of Medical Sciences, University of Kragujevac (MP 01/14). No potential conflicts of interest relevant to this article were reported.

\section{REFERENCES}

1. Kaplan MM, Gershwin ME. Primary biliary cirrhosis. N Engl J Med. 2005; 353(12): 1261-1273.

2. Bergasa NV. Pruritus and fatigue in primary biliary cirrhosis. Clin Liver Dis. 2003; 7: 879-900.

3. Selmi C, Bowlus CL, Gershwin ME, Coppel RL. Primary biliary cirrhosis. Lancet. 2011; 377: 1600-1609.

4. Gershwin ME, Mackay IR. The causes of primary biliary cirrhosis: Convenient and inconvenient truths. Hepatology. 2008; 47(2): 737-745.

5. Hirschfield GM, Gershwin ME. The immunobiology and pathophysiology of primary biliary cirrhosis. Annu Rev Pathol. 2013; 8: 303-330.

6. Walker JG, Doniach D, Roitt IM, Sherlock S. Serological tests in diagnosis of primary biliary cirrhosis. Lancet $1965 ; 1$ : 827-831.

7. Fussey SP, Guest JR, James OF, Bassendine MF, Yeaman SJ. Identification and analysis of the major M2 autoantigens in primary biliary cirrhosis. Proc. Natl. Acad. Sci. USA 1988; 85: 8654-8658.

8. Moteki S, Leung PS, Dickson ER, et al. Epitope mapping and reactivity of autoantibodies to the $\mathrm{E} 2$ component of 2-oxoglutarate dehydrogenase complex in primary biliary cirrhosis using recombinant 2-oxoglutarate dehydrogenase complex. Hepatology. 1996; 23(3): 436-444.

9. Miller FW, Alfredsson L, Costenbader KH, et al. Epidemiology of environmental exposures and human autoimmune diseases: findings from a National Institute of Environmental Health Sciences Expert Panel Workshop. J Autoimmun. 2012; 39(4): 259-271.

10. Selmi C, Leung PS, Sherr DH, Diaz et al. Mechanisms of environmental influence on human autoimmunity: a National Institute of Environmental Health Sciences expert panel workshop. J Autoimmun. 2012; 39(4): 272-284.

11. Selmi C, Balkwill DL, Invernizzi P, et al. Patients with primary biliary cirrhosis react against a ubiquitous xenobiotic-metabolizing bacterium. Hepatology. 2003; 38(5): 1250-1257.

12. Mattner J, Savage PB, Leung P, et al. Liver autoimmunity triggered by microbial activation of natural killer $\mathrm{T}$ cells. Cell Host Microbe. 2008; 3(5): 304-315.

13. Rieger R, Leung PS, Jeddeloh MR, et al. Identification of 2-nonynoic acid, a cosmetic component, as a potential trigger of primary biliary cirrhosis. J Autoimmun. 2006; 27(1): 7-16.

14. Wakabayashi K, Lian ZX, Leung PS, et al. Loss of tolerance in C57BL/6 mice to the autoantigen E2 subunit of pyruvate dehydrogenase by a xenobiotic with ensuing biliary ductular disease. Hepatology. 2008; 48(2): 531-540.

15. Wakabayashi K, Yoshida K, Leung PS, et al. Induction of autoimmune cholangitis in non-obese diabetic (NOD).1101 mice following a chemical xenobiotic immunization. Clin Exp Immunol. 2009; 155(3): 577-586.

16. Ambrosini YM, Yang GX, Zhang W, et al. The multi-hit hypothesis of primary biliary cirrhosis: polyinosinicpolycytidylic acid (poly I:C) and murine autoimmune cholangitis. Clin Exp Immunol. 2011; 166(1): 110-120.

17. Wu SJ, Yang YH, Tsuneyama K, et al. Innate immunity and primary biliary cirrhosis: activated invariant natural killer $\mathrm{T}$ cells exacerbate murine autoimmune cholangitis and fibrosis. Hepatology. 2011; 53(3): 915-925.

18. Gershwin ME, Ansari AA, Mackay IR, et al. Primary biliary cirrhosis: an orchestrated immune response against epithelial cells. Immunol Rev. 2000; 174: 210-225.

19. Kita H, Matsumura S, He XS, et al. Quantitative and functional analysis of PDC-E2-specific autoreactive cytotoxic T lymphocytes in primary biliary cirrhosis. J Clin Invest. 2002; 109(9): 1231-1240.

20. Chuang YH, Lan RY, Gershwin ME. The immunopathology of human biliary cell epithelium. Semin Immunopathol. 2009; 31(3): 323-331.

21. Kimura Y, Leung PS, Kenny TP, et al. Differential expression of intestinal trefoil factor in biliary epithelial cells of primary biliary cirrhosis. Hepatology. 2002; 36(5): 1227-1235.

22. Lleo A, Invernizzi P, Mackay IR, Prince $H$, Zhong RQ, Gershwin ME. Etiopathogenesis of primary biliary cirrhosis. World J Gastroenterol. 2008; 14(21): 3328-3337. 
23. Odin JA, Huebert RC, Casciola-Rosen L, LaRusso NF, Rosen A. Bcl-2-dependent oxidation of pyruvate dehydrogenase-E2, a primary biliary cirrhosis autoantigen, during apoptosis. J Clin Invest. 2001; 108(2): 223-232.

24. Lleo A, Selmi C, Invernizzi P, et al. Apotopes and the biliary specificity of primary biliary cirrhosis. Hepatology. 2009; 49(3): 871-879.

25. Lleo A, Bowlus CL, Yang GX, et al. Biliary apotopes and anti-mitochondrial antibodies activate innate immune responses in primary biliary cirrhosis. Hepatology. 2010; 52(3): 987-998.

26. Van de Water J, Gerson LB, Ferrell LD, et al. Immunohistochemical evidence of disease recurrence after liver transplantation for primary biliary cirrhosis. Hepatology. 1996; 24(5): 1079-1084.

27. Van de Water J, Turchany J, Leung PS, et al. Molecular mimicry in primary biliary cirrhosis. Evidence for biliary epithelial expression of a molecule cross-reactive with pyruvate dehydrogenase complex-E2. J Clin Invest. 1993; 91(6): 2653-2664.

28. Tsuneyama K, Van de Water J, Leung PS, et al. Abnormal expression of the E2 component of the pyruvate dehydrogenase complex on the luminal surface of biliary epithelium occurs before major histocompatibility complex class II and BB1/B7 expression. Hepatology. 1995; 21(4): 1031-1037.

29. Matsumura S, Van De Water J, Leung P, et al. Caspase induction by IgA antimitochondrial antibody: IgA-mediated biliary injury in primary biliary cirrhosis. Hepatology. 2004; 39(5): 1415-1422.

30. Kita H, Naidenko OV, Kronenberg M, et al. Quantitation and phenotypic analysis of natural killer $\mathrm{T}$ cells in primary biliary cirrhosis using a human CD1d tetramer. Gastroenterology. 2002; 123(4): 1031-1043.

31. Kita H, Lian ZX, Van de Water J, et al. Identification of HLA-A2-restricted CD8(+) cytotoxic T cell responses in primary biliary cirrhosis: $\mathrm{T}$ cell activation is augmented by immune complexes cross-presented by dendritic cells. J Exp Med. 2002; 195(1): 113-123.

32. Shimoda S, Miyakawa H, Nakamura M, et al. CD4 Tcell autoreactivity to the mitochondrial autoantigen PDC-E2 in AMA-negative primary biliary cirrhosis. J Autoimmun. 2008; 31(2): 110-115.

33. Van de Water J, Ansari A, Prindiville T, et al. Heterogeneity of autoreactive $\mathrm{T}$ cell clones specific for the $\mathrm{E} 2$ component of the pyruvate dehydrogenase complex in primary biliary cirrhosis. J Exp Med. 1995; 181(2): 723-733.

34. Oo YH, Weston CJ, Lalor PF, et al. Distinct roles for CCR4 and CXCR3 in the recruitment and positioning of regulatory $\mathrm{T}$ cells in the inflamed human liver. J Immunol. 2010; 184(6): 2886-2898.

35. Lan RY, Cheng C, Lian ZX, et al. Liver-targeted and peripheral blood alterations of regulatory $\mathrm{T}$ cells in primary biliary cirrhosis. Hepatology. 2006; 43(4): 729-737.
36. Lan RY, Salunga TL, Tsuneyama K, et al. Hepatic IL-17 responses in human and murine primary biliary cirrhosis. J Autoimmun. 2009; 32(1): 43-51.

37. Harada K, Isse K, Nakanuma Y. Interferon gamma accelerates NF-kappaB activation of biliary epithelial cells induced by Toll-like receptor and ligand interaction. J Clin Pathol. 2006; 59(2): 184-190.

38. Shimoda S, Harada K, Niiro H, et al. CX3CL1 (fractalkine): a signpost for biliary inflammation in primary biliary cirrhosis. Hepatology. 2010; 51(2): 567-575.

39. Chuang YH, Lian ZX, Yang GX, et al. Natural killer T cells exacerbate liver injury in a transforming growth factor beta receptor II dominant-negative mouse model of primary biliary cirrhosis. Hepatology. 2008; 47(2): 571-580.

40. Krams SM, Dorshkind K, Gershwin ME. Generation of biliary lesions after transfer of human lymphocytes into severe combined immunodeficient (SCID) mice. J Exp Med. 1989; 170(6): 1919-1930.

41. Irie J, Wu Y, Wicker LS, et al. NOD.c3c4 congenic mice develop autoimmune biliary disease that serologically and pathogenetically models human primary biliary cirrhosis. J Exp Med. 2006; 203(5): 1209-1219.

42. Oertelt S, Lian ZX, Cheng CM, et al. Anti-mitochondrial antibodies and primary biliary cirrhosis in TGFbeta receptor II dominant-negative mice. J Immunol. 2006; 177(3): 1655-1660.

43. Wakabayashi K, Lian ZX, Moritoki Y, et al. IL-2 receptor alpha(-/-) mice and the development of primary biliary cirrhosis. Hepatology. 2006; 44(5): 1240-1249.

44. Hsu W, Zhang W, Tsuneyama K, et al. Differential mechanisms in the pathogenesis of autoimmune cholangitis versus inflammatory bowel disease in interleukin-2Ralpha(-/-) mice. Hepatology. 2009; 49(1): 133-140.

45. Amano K, Leung PS, Rieger R, et al. Chemical xenobiotics and mitochondrial autoantigens in primary biliary cirrhosis: identification of antibodies against a common environmental, cosmetic, and food additive, 2-octynoic acid. J Immunol. 2005; 174(9): 5874-5883.

46. Naiyanetr P, Butler JD, Meng L, et al. Electrophilemodified lipoic derivatives of PDC-E2 elicits anti-mitochondrial antibody reactivity. J Autoimmun. 2011; 37(3): 209-216.

47. Rieger R, Leung PS, Jeddeloh MR, et al. Identification of 2-nonynoic acid, a cosmetic component, as a potential trigger of primary biliary cirrhosis. J Autoimmun. 2006; 27(1): 7-16.

48. Leung PS, Park O, Tsuneyama K, et al. Induction of primary biliary cirrhosis in guinea pigs following chemical xenobiotic immunization. J Immunol. 2007; 179(4): 2651-2657.

49. Leung PS, Quan C, Park O, et al. Immunization with a xenobiotic 6-bromohexanoate bovine serum albumin conjugate induces antimitochondrial antibodies. J Immunol. 2003; 170(10): 5326-5332. 